\title{
Molecular Detection of the Laurel Wilt Fungus, Raffaelea lauricola
}

\author{
A. Jeyaprakash, D. A. Davison, and T. S. Schubert, Florida Department of Agriculture and Consumer Services, Division of Plant \\ Industry, Bureau of Entomology, Nematology and Plant Pathology, Gainesville 32608
}

\begin{abstract}
Jeyaprakash, A., Davison, D. A., and Schubert, T. S. 2014. Molecular detection of the laurel wilt fungus, Raffaelea lauricola. Plant Dis. 98:559-564.

The laurel wilt disease fungus, Raffaelea lauricola, is killing redbay trees, spreading rapidly in the U.S. southeastern coastal plain forest, and posing a serious threat to the avocado industry in Florida. A molecular tool is urgently required to facilitate detection of this pathogen. The $5^{\prime}$ region of the large ribosomal RNA (28S) gene is highly variable among Raffaelea spp. and ideal for this purpose but amplification of this sequence from $R$. lauricola has been difficult. Different amplification conditions were tested and a high-fidelity polymerase chain reaction (PCR) procedure utilizing a dNTP mix containing 7deaza-dGTP was found to reliably amplify $28 \mathrm{~S}$ sequences from $R$. lauricola. Sequencing the amplified products or cloned inserts also turned out to be difficult and required using a custom-blended

dGTP-BigDye v3.1. Three GC-rich stem and loop or cruciform secondary structures were discovered, which may have interfered with amplification. This improved protocol made it possible to partially characterize the internal transcribed spacers sequence from $R$. lauricola, which also has interfering secondary structures. A TaqMan real-time PCR assay was designed using the species-specific $28 \mathrm{~S}$ sequences and this allowed detection of $R$. lauricola from wood tissues or cultures. Wood tissues from symptomatic redbay, avocado, and sassafras trees in Florida were screened using this TaqMan assay and several were found to test positive for $R$. lauricola. Results were further confirmed by performing Koch's postulates for avocado specimens collected from commercial grooves.
\end{abstract} sequencing mix containing $1 \mathrm{M}$ betaine, 5\% dimethyl sulfoxide, and
The ambrosia beetle, Xyleborus glabratus Eichhoff (Coleoptera: Curculionidae: Scolytinae), was inadvertently introduced into Savannah, GA in 2002 through infested wooden packing materials that arrived from an unknown Asian destination $(6,14)$. This beetle carries several fungal symbionts, including Raffaelea lauricola T.C. Harr., Fraedrich \& Aghayeva, in its specialized mouth parts (mycangial pouches; 7,9). The adult beetle makes bore holes in the tree trunk, inoculating the wood with $R$. lauricola, which colonizes and causes the laurel wilt disease. Extensive mortality of redbay (Persea borbonia (L.) Spreng) and other members of the family Lauraceae is occurring in the coastal plain forest of Georgia, South Carolina, and Florida due to the spread of this beetle and the associated fungus. The disease is now known to affect avocado $(P$. americana Mill) in Florida (12). In addition, camphor (Cinnamomum camphora (L.) Sieb) and sassafras (Sassafras albidum L.) trees are also dying in Florida due to beetle activities, followed by the inevitable infection by $R$. lauricola $(17,18)$. Redbay trees with laurel wilt were detected recently in Mississippi (15). There have been other reports extending the host and geographic range of the pathogen (Alabama, North Carolina, and so on), most relaying on $18 \mathrm{~S}$ identifications (www.fs.fed.us/r8/ foresthealth/laurelwilt).

Surveillance is being carried out in Florida to monitor the spread of this disease. When beetle damage (bore holes or beetle frass) is suspected in any avocado trees, molecular diagnosis is often sought to confirm the presence of $R$. lauricola because several Raffaelea spp. are known to exist in $X$. glabratus $(7,10)$, and they are often hard to distinguish.

Currently, the genomic DNA extracted from a culture of Raffaelea generated from a suspected tree is amplified by a standard polymerase chain reaction (Std-PCR) procedure. A small ribosomal RNA (rRNA) (18S) sequence is amplified and used to confirm

Corresponding author: A. Jeyaprakash,

E-mail: ayyamperumal.jeyaprakash@freshfromflorida.com

Accepted for publication 5 November 2013.

http://dx.doi.org/10.1094/PDIS-08-13-0894-RE

(C) 2014 The American Phytopathological Society
$R$. lauricola presence $(12,15,17,18)$; however, this marker displays low variability among Raffaelea spp. For this reason, taxonomists often emphasize using the highly variable sequences present in the internal transcribed spacers (ITS1 and -2) to detect and identify fungi (19). The problem with ITS amplification from $R$. lauricola was noted early on (6); therefore, the D1/D2 region of the large rRNA (28S) gene has been proposed as the standard for Raffaelea identification $(1,7,8,10)$. However, attempts to amplify the highly variable ITS and $28 \mathrm{~S}$ marker sequences from $R$. lauricola using Std-PCR technique have been difficult. Often, PCR artifacts were generated during these attempts, producing misleading sequence information. This produced lots of false negatives, and even infected trees that produced fungal culture with spore morphology matching $R$. lauricola (9) failed to produce PCR products. A difficult but a successful amplification seems to have allowed detecting only a partial sequence from $R$. lauricola $28 \mathrm{~S}$ (545 bp) locus (GenBank accession number EU123077) (7). Even though PCR (16) is a popular technique to amplify sequences, failure could still be possible due to (i) trace amounts of plant pathogen DNA present mixed in with abundant plant DNA and (ii) marker sequences containing high GC- or AT-rich regions that produce stem and loop or cruciform secondary structures. Hence, an optimized protocol is urgently required to utilize either the $28 \mathrm{~S}$ or ITS marker from $R$. lauricola to design a reliable molecular assay. An attempt was made to analyze both markers and design a reliable molecular detection protocol.

\section{Materials and Methods}

Specimens. Several suspected redbay, sassafras, avocado, and bay laurel (Laurus nobilis L.) trees showing laurel wilt disease symptoms were noticed in different locations of Florida (Table 1). They often showed bore holes in the sap wood due to beetle damage. Beetle frass and stain were noticed. Initially, dead branches appeared but, soon, the affected trees started wilting or died. Samples of wood (approximately 3 to $10 \mathrm{~cm}$ ) were collected from suspect trees by several pest survey inspectors and submitted for diagnosis. A handheld drill bit was used to bore through the suspected wood and obtain some wood pieces for fungal culturing or DNA extraction. The $R$. lauricola holotype culture C2339 was obtained from Centralbureau voor Schimmelcultures (The Netherlands) for comparison. 
Culturing. The Raffaelea sp. was cultured from infected wood pieces on malt extract agar plates containing streptomycin $(0.01 \%)$ and cyclohexamide $(0.01 \%)$ at $30^{\circ} \mathrm{C}$ in darkness for 10 days (9).

DNA extraction and amplifications. Wood pieces were frozen in liquid nitrogen and finely powdered using a sterile $3-\mathrm{mm}$ glass bead in a Minibeadbeater 96+ (Biospec Products Inc.). A DNeasy Plant Mini Kit (Qiagen Inc.) was used to extract genomic DNA from either cells harvested from a fungal culture plate using sterile HyClone water (5 ml; Thermo Fisher Scientific) or finely powdered wood pieces $(100 \mathrm{mg})$, and eluted using $100 \mu \mathrm{l}$ of sterile HyClone water. Primers were obtained from a commercial source (Integrated DNA Technologies, Inc.) (Table 2). Std-PCR (16) was performed in a $25-\mu$ reaction volume containing DNA $(1 \mu \mathrm{l})$, forward and reverse primers (100 pmol; Table 2$)$, buffer (10 mM Tris [pH 8.3], $50 \mathrm{mM}$ potassium chloride, and $1.5 \mathrm{mM}$ magnesium chloride), a dNTP mix $(200 \mu \mathrm{M})$, and Taq DNA polymerase (1 unit; Takara Bio). Std-PCR profile include three linked cycles: (i) $94^{\circ} \mathrm{C}$ for $2 \mathrm{~min}(1 \mathrm{cycle})$; (ii) $94^{\circ} \mathrm{C}$ for $20 \mathrm{~s}, 50^{\circ} \mathrm{C}$ for $18 \mathrm{~S}$ (varied for other markers), and $72^{\circ} \mathrm{C}$ for 2 min $\left(35\right.$ cycles); and (iii) $72^{\circ} \mathrm{C}$ for $7 \mathrm{~min}$ ( 1 cycle). High-fidelity (Hf)-PCR (2) was performed in a $50-\mu \mathrm{l}$ reaction volume containing DNA templates $(2 \mu \mathrm{l})$, forward and reverse primers (200 pmol; Table 2), buffer (50 mM Tris [pH 9.2], $16 \mathrm{mM}$ ammonium sulfate, and $1.75 \mathrm{mM}$ magnesium chloride), a dNTP mix composed of $350 \mu \mathrm{M}$ dATP, dTTP, and dCTP plus $87.5 \mu \mathrm{M}$ dGTP and $262.5 \mu \mathrm{M}$ 7-deaza-dGTP (Life Technologies-Invitrogen), Taq (5 units; Takara Bio), and ACCUZYME (0.5 unit; Bioline Inc.) with a $100-\mu l$ mineral oil overlay. Hf-PCR profile included three linked cycles: (i) $94^{\circ} \mathrm{C}$ for 2 min (1 cycle); (ii) $94^{\circ} \mathrm{C}$ for $10 \mathrm{~s}, 45^{\circ} \mathrm{C}$ for $30 \mathrm{~s}$ for $28 \mathrm{~S}$ or $53^{\circ} \mathrm{C}$ for $30 \mathrm{~s}$ for ITS, and $68^{\circ} \mathrm{C}$ for $\left.1 \mathrm{~min}\right)\left(10\right.$ cycles); and (iii) $94^{\circ} \mathrm{C}$ for $10 \mathrm{~s}, 45^{\circ} \mathrm{C}$ for $30 \mathrm{~s}$ for $28 \mathrm{~S}$ or $53^{\circ} \mathrm{C}$ for $30 \mathrm{~s}$ for ITS, and $68^{\circ} \mathrm{C}$ for 1 min plus $20 \mathrm{~s}$ added for every consecutive cycle ( 20 cycles). A GeneAmp PCR System 9700 (Life Technologies-Applied Biosystems) was used for all amplifications.

Cloning. The PCR products obtained from each sample were cloned into pCR2.1 TOPO by following the manufacturer's recommended procedure (Life Technologies-Invitrogen).

Sequencing. Hf-PCR products $(40 \mu \mathrm{l})$ were cleaned using a High-Pure column (Roche Diagnostics Corporation) and eluted using sterile HyClone water $(40 \mu \mathrm{l})$. Sequencing reactions were performed using Hf-PCR products $(4 \mu \mathrm{l})$ or plasmids carrying the cloned inserts (100 ng), primer (Table 2), and the BigDye Terminator v3.0 Cycle Sequencing RR-100 mix as suggested by the manufacturer (Life Technologies-Applied Biosystems) or a customblended mix containing the dGTP-BigDye Terminator v3.1 Cycle Sequencing RR-100 mix, 5\% dimethyl sulfoxide (DMSO; Thermo Fisher Scientific), and $1 \mathrm{M}$ betaine (Sigma-Aldrich). The sequencing reactions were denatured using the BigDye XTerminator purification kit and loaded into an ABI 3130 Genetic Analyzer (Life Technologies-Applied Biosystems). Data collected used ABI Data Collection v3.0 and Sequencing Analysis v5.2 softwares. Sequences with high Phred values ( $>20)$ were aligned with the sequences obtained from the GenBank BLAST search in MEGA 5. The sequences were analyzed using mFold software (21) to detect secondary structures.

TaqMan real-time PCR amplifications. Genomic DNA $(1 \mu \mathrm{l})$ extracted was amplified using $10 \mathrm{pmol}$ each of a forward primer (LW-28S-F1), a reverse primer (LW-28S-R1), and a TaqMan probe (LW-28Sp) (Table 2); and a Takara Ex-Taq master mix $(12.5 \mu \mathrm{l})$ (Takara Bio) in a $25-\mu$ l volume. The amplification profile included (i) $95^{\circ} \mathrm{C}$ for $30 \mathrm{~s}\left(1\right.$ cycle) and (ii) $95^{\circ} \mathrm{C}$ for $15 \mathrm{~s}, 65^{\circ} \mathrm{C}$ for $30 \mathrm{~s}$, and $72^{\circ} \mathrm{C}$ for $30 \mathrm{~s}$ (40 cycles). Amplification was performed using a Smart Cycler (Cepheid) and cycle threshold $(\mathrm{Ct})$ values recorded for each sample.

Koch's postulates for laurel wilt disease. If any avocado specimen from a commercial groove tested positive for laurel wilt disease, then Koch's postulates were performed. A small bore hole was made in the trunk of a clean, healthy avocado plant growing in the greenhouse and filled with $100 \mu \mathrm{l}$ of a fungal spore suspension (approximately $10^{6}$ spores $/ \mathrm{ml}$ ). The inoculated site was wrapped in parafilm and the plant monitored for 4 weeks. If the inoculated plant died, then a small wood piece was obtained away from the inoculation site and the laurel wilt fungus was cultured as described above. Genomic DNA was extracted from this fungal specimen and tested using TaqMan real-time PCR for R. lauricola identification.

\section{Results}

Suspected laurel wilt disease-affected redbay, avocado, and bay laurel trees in Florida. Fungal cultures were generated from

Table 1. List of specimens collected from Florida that tested positive for laurel wilt disease ${ }^{a}$

\begin{tabular}{llll}
\hline Specimen number & & Location & Host \\
\hline 51568 & Miami, FL & Avocado & Hf-PCR and sequencing \\
59989 & Miami, FL & Avocado & Hf-PCR and sequencing \\
66998 & Miami, FL & Avocado & TaqMan RT-PCR \\
71549 & Miami, FL & Avocado & TaqMan RT-PCR \\
72177 & Miami, FL & Avocado & TaqMan RT-PCR \\
72178 & Miami, FL & Avocado & TaqMan qRT-PCR \\
51743 & Coral Gables, FL & Bay laurel & Hf-PCR and sequencing \\
69678 & Withalacoochie State Forest (Hernando County), FL & Redbay & TaqMan RT-PCR \\
71975 & Taylor, FL & Redbay & TaqMan RT-PCR \\
72122 & Everglades Swamp (Miami-Dade County), FL & TaqMan RT-PCR \\
72123 & Everglades Swamp (Miami-Dade County), FL & TaqMan RT-PCR \\
62611 & Gainesville, FL & Redbay & TaqMan RT-PCR \\
\hline
\end{tabular}

a Optimized high-fidelity polymerase chain reaction (Hf-PCR), sequencing, and TaqMan real-time (RT)-PCR procedures were performed.

Table 2. List of primers and probe used for amplification of Raffaelea lauricola

\begin{tabular}{|c|c|c|c|}
\hline Marker & Primer or probe & Sequence & Reference \\
\hline $18 \mathrm{~S}$ & NS1 & 5'-GTA GTC ATA TGC TTG TCT C-3' & 19 \\
\hline $18 \mathrm{~S}$ & NS4 & 5'-CTT CCG TCA ATT CCT TTA AG-3' & 19 \\
\hline ITS & ITS4 & $5^{\prime}$-TCC TCC GCT TAT TGA TAT GC-3' & 19 \\
\hline ITS & ITS5 & 5'-GGA AGT AAA AGT CGT AAC AAG G-3' & 19 \\
\hline $28 \mathrm{~S}$ & LROR & $5^{\prime}$-ACC CGC TGA ACT TAA GC-3' & 19 \\
\hline $28 \mathrm{~S}$ & LR3 & $5^{\prime}$-CCG TGT TTC AAG ACG GG-3' & 19 \\
\hline $28 \mathrm{~S}$ & LR5 & $5^{\prime}$-TCC TGA GGG AAA CTT CG-3' & 19 \\
\hline $28 \mathrm{~S}$ & LW28S-F1 & $5^{\prime}$-CGA GTG AAG CGG CAA CAG CTC A-3' & This study \\
\hline $28 \mathrm{~S}$ & LW28S-R1 & 5'-CGC CGC CAG AAG CGT CCT CTC-3' & This study \\
\hline $28 \mathrm{~S}$ & LW28Sp & (6FAM)-CCG CGG GCC CGA GTT GTA CTT-(BHQ) & This study \\
\hline
\end{tabular}


the suspected laurel wilt disease samples and their spore morphology (Fig. 1) was found to be very similar to R. lauricola (9). Selected fungal cultures from redbay, avocado, and bay laurel were used for molecular analyses to confirm the morphological identification.

Amplification of 18S, 28S, and ITS marker sequences from $R$. lauricola (holotype culture: C2339). A holotype culture of $R$. lauricola (C2339) was first analyzed. Efforts to amplify the $28 \mathrm{~S}$ and ITS marker sequences from this holotype culture specimen C2339 using the Std-PCR procedure have failed consistently in our hands but amplification of $18 \mathrm{~S}$ sequence was successful. The $18 \mathrm{~S}$ sequence $(1,035 \mathrm{bp})$ obtained from the PCR products overlapped and produced $100 \%$ identity with the $R$. lauricola sequences existing in the GenBank (FJ514097, GQ996063, GQ329704, and EU170267) in the overlap.

The Hf-PCR procedure has been shown to be at least 10,000fold more efficient than Std-PCR to amplify fungal marker sequences (3). Hence, the Hf-PCR procedure was tried instead of Std-PCR to amplify the 28S and ITS markers; however, this effort also did not generate any products, indicating that unusual sequences or secondary structures could be interfering with amplification process. Adding 5 or $10 \%$ DMSO to the Hf-PCR mix was tried because this reagent was known to weaken secondary structures (20); however, this effort also did not produce any amplified products. Then, a dNTP mix containing 7-deaza-dGTP was tried in the Hf-PCR mix. This modification has worked and did allow amplification of the $28 \mathrm{~S} 5^{\prime}$ region $(0.9 \mathrm{~kb})$ using the LROR and LR5 primers (Table 2$)$ and the ITS region $(0.6 \mathrm{~kb})$ using the ITS 4 and ITS5 primers (Table 2). The amplified Hf-PCR products containing 7-deaza-dGTP stained lightly with SYBR Safe dye as expected because the dye does not bind between the 7-deaza-G and $\mathrm{C}$ base pairings. Still, a faint DNA band was clearly visible (Fig. 2).

An attempt to sequence these amplified 28S and ITS products using the BigDye Terminator v3.0 sequencing mix was only partially successful. The products were cloned into pCR2.1 TOPO and the plasmid carrying an insert was used as a template for sequencing; however, these attempts also produced only partial success. Interference by unusual sequences or secondary structure in the sequencing reaction was suspected to cause the enzyme to prematurely stop during the extension process. A custom-blend mix containing $1 \mathrm{M}$ betaine, 5\% DMSO, and dGTP-BigDye Terminator v3.1 Cycle Sequencing RR-100 mix was tried, and this allowed us to completely sequence the $28 \mathrm{~S}$ products $(932 \mathrm{bp}$ ) (GenBank accession number KF515710) from LROR to LR5 primer binding sites but produced only a partial sequence for the $0.6-\mathrm{kb}$ ITS prod- ucts from the ITS4 primer binding site to the middle of ITS1 spacer (486 bp) (KF515711). A strong secondary structure seems to exist between the partial ITS sequence obtained and the ITS5 primer binding site in the $18 \mathrm{~S} 3^{\prime}$ end. Both forward and reverse sequencing reactions failed to resolve this structure.

The sequences obtained were further characterized. The complete $28 \mathrm{~S}$ sequence $(932 \mathrm{bp}$ ) was found to overlap a partial $R$. lauricola sequence deposit existing in the GenBank (EU123077) and produced a $100 \%$ identity in the overlapped region (545 bp). A BLAST search revealed that the sequences outside the overlap are unique and not represented in the GenBank. The GC content for the entire $932 \mathrm{bp}$ of the $28 \mathrm{~S}$ fragment is $60 \%$ but three segments within this marker have been found to be GC rich: (i) a 55-bp segment from base position number 413 to 467 (87\% GC), (ii) a 89-bp segment from base position number 476 to 564 (74\% GC), and (iii) a 36-bp segment from base position number 565 to 600 (69\% GC),

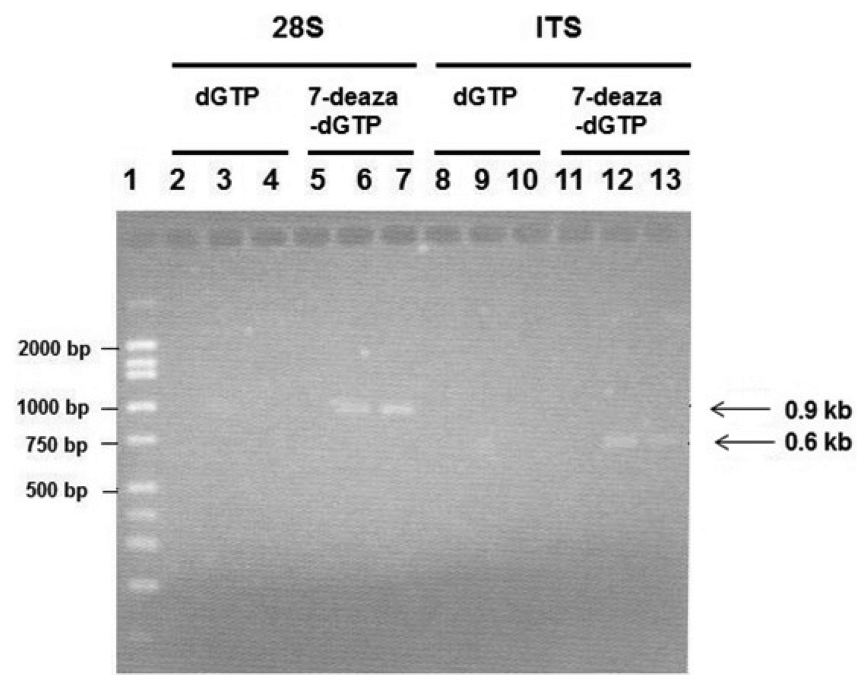

Fig. 2. High-fidelity polymerase chain reaction amplification of genomic DNA extracted from Raffaelea lauricola type culture C2339 using two different dNTP mixes. The 28S-amplified products using a standard dNTP mix containing dGTP (lanes 2-4) and a modified dNTP mix containing 7-deaza-dGTP (lanes 5-7) are shown here. The internal transcribed spacer (ITS)-amplified products using a standard dNTP mix containing dGTP (lanes 8-10) and a modified dNTP mix containing 7-deaza-dGTP (lanes 11-13) are shown here. Lane details: Lane 1, DNA marker; lanes 2, 5, 8, and 11, no DNA control; and lanes 3, 4, 6, 7, 9, 10, 12, and $13, \mathrm{C} 2339$.
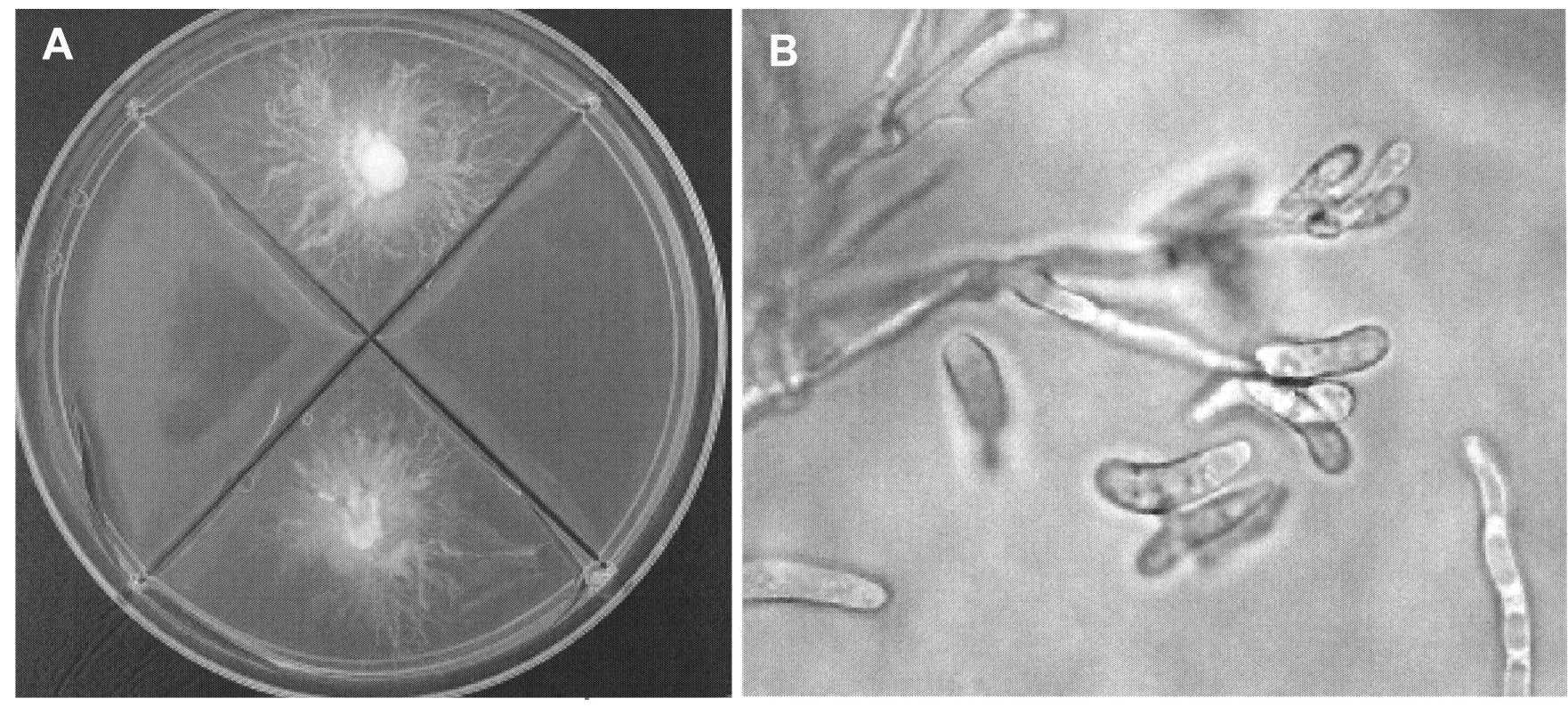

Fig. 1. Raffaelea culture generated from an avocado tree showing laurel wilt symptoms. A, Mycelia developing on a culture plate. B, Details of mycelia and spores. 


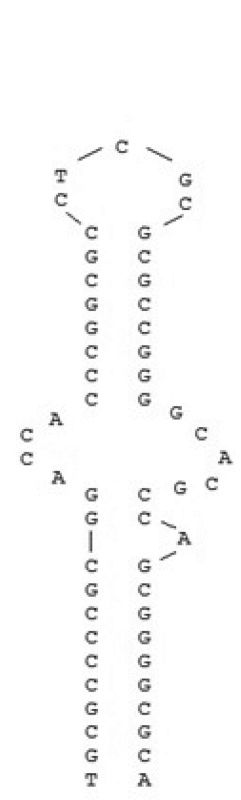

A

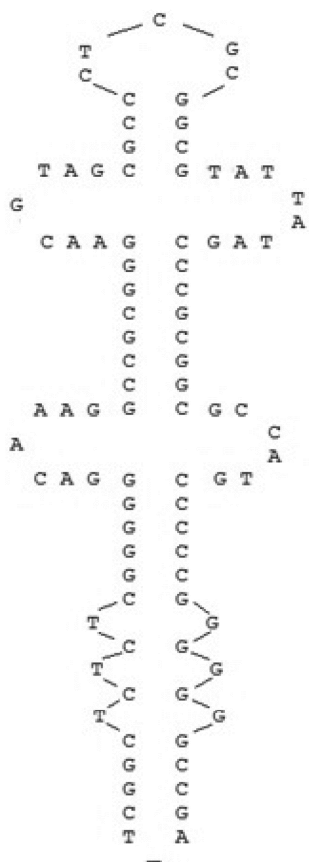

B

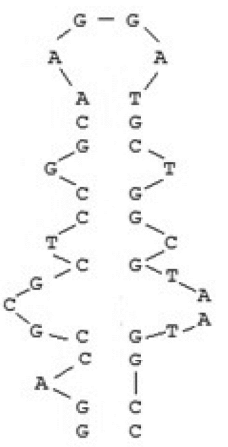

C
Fig. 3. Mfold-generated secondary structures from three GC-rich segments of the 932-bp amplified Raffaelea lauricola 28S sequence. A, Segment number 1 (from base position number 413 to $467 ; 55$ bp); B, segment number 2 (from base position number 476 to $564 ; 89 \mathrm{bp}$ ); and $\mathbf{C}$, segment number 3 (from base position number 565 to $600 ; 36 \mathrm{bp})$. near the LR3 primer (Table 2) binding site. All these GC-rich regions produced strong stem and loop or cruciform secondary structures (Fig. 3) which seem to have interfered with the amplification.

The partial ITS sequence obtained (486 bp) contains an expected partial $28 \mathrm{~S} 5^{\prime}$ region ( $57 \mathrm{bp}, 49 \% \mathrm{GC}$ ) from the ITS4 primer binding site, a complete ITS2 spacer (161 bp, 81\% GC), a complete 5.8S (154 bp, 49\% GC), and a partial ITS1 spacer (114 bp, 62\% GC). It appears that a strong secondary structure or a GC-rich region exists between this sequenced segment and the ITS5 primer (Table 2) binding site located in the $18 \mathrm{~S} 3^{\prime}$ region. The ITS2 spacer sequence (161 bp) was analyzed and found to contain two strong GC-rich stem and loop structures (data not shown); still, the custom sequencing blend was able to resolve them. The ITS1 spacer sequence, on the other hand, could be sequenced only partially (114 bp); a strong secondary structure that exists beyond this 114bp sequence remains unresolved and their exact sequence is unknown.

Screening symptomatic avocado and bay laurel trees for $\boldsymbol{R}$. lauricola. Genomic DNA obtained from fungal cultures of avocado (specimen numbers 51568 and 59989) and bay laurel (number 51743) were amplified using this optimized protocol and sequenced. The $28 \mathrm{~S}$ sequences $(932 \mathrm{bp})$ produced $100 \%$ identity with those obtained from the $R$. lauricola type culture (C2339). Sequencing the ITS products also produced $100 \%$ identity with the type culture (C2339) excluding an ITS1 spacer region containing the strong secondary structure $(486 \mathrm{bp})$. The $18 \mathrm{~S}$ products obtained from these specimens using Std-PCR also produced $100 \%$ identity with the existing $R$. lauricola sequence in the GenBank (FJ514097; $1,035 \mathrm{bp}$ ). These findings allowed us to conclude that these three specimens test positive for $R$. lauricola.

A TaqMan real-time PCR assay detects $R$. lauricola from suspected redbay, avocado, and sassafras. In order to design a

\section{Raffaelea Species}

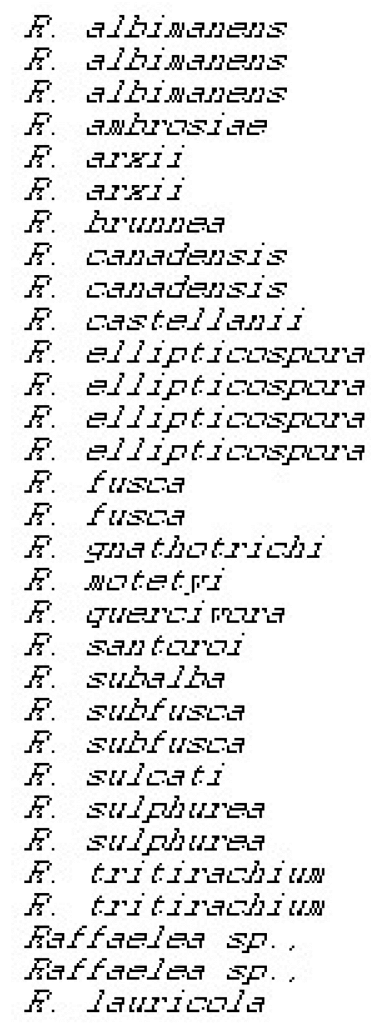

Probe LW285p

\section{GenBank\# 285 rRHA Sequence}

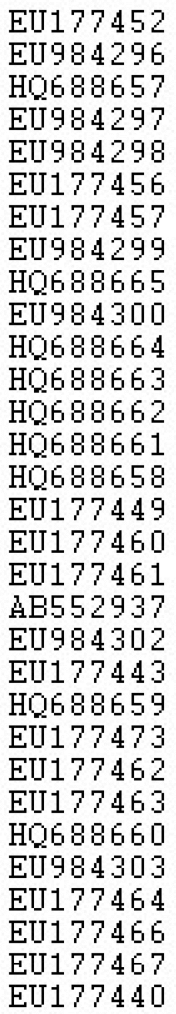

87 114 -COCCT-GGGGGGCOC-GAGTTGTACTT TCCCCT-GGGGGGCCCCGAGTTGTACTT - CCCCG-GGGGGGCCC-GAGTTGTACTT CTTC----GGGAGCCCGAGTTGTAATT COCC---GCGGGGGTCOGAGTTGTARTT CCCC--OGCTGGGGGCCGAGTTGTAATT COCCCGCGGGGGGGTCTGAGTTGTARTT COCCOG-CGGGGGGCOCGAGTTGTACTT CCCC-G-CGGGGG-CCCGAGTTGTACTT COCTC---OGGGGTCCGCATTGTAATT CCCCCCGGGGGG-CCCGAGTTGTAATT COCCOCCGGGGGGGCCCGAGTTGTAATT COCC-- GGGGGGGCCOGAGTTGTAAT COCC--GGGGGGGCOCGAGTTGTAATT CTTC----GGGGGCOCGAGTTGTARTT COTC---- GGGGGGCGGAGTTGTAATT COCC--GCGGGGGTCCGAGTTGTARTT COCCC---GGGGGCOCGAGTTGTAATC COCC----GGGGGCOCGAGTTGTARTC $\mathrm{COCCOG-GGGGGGCOC-GAGTTGTACTT}$ COCCT--GGGGGGCCC-GAGTTGTAAT CCCT-----GGGGGCCCGAGTTGTAAT COTC----GGGGGCCOGAGTTGTAATT COCCT--GGGGGGCOC-GAGTTGTACTT CCCCG---GGGGGTCCGAGTTGTAATC CCC-----6GGGGCCOGAGTTGTAATC CCOCT--GGGGGGTCC-GAGTTGTAATT COCTT--GGGGGGTCC-GAGTTGTAAT CCC-G-6GGGGG-CCCGAGTTGTACTT CCCC--GGGGGGCCC-GAGTTGTAAT CCGC------GGGCCOGAGTTGTACTT

GCGC GGGCOCGAGTTGTACTT

Fig. 4. Raffaelea spp. 28S ribosomal RNA (rRNA) sequences available in the GenBank are aligned using CLUSTAL W and the character positions 87 to 114 displaying high variability are shown here. 
TaqMan real-time PCR assay for $R$. lauricola, the $28 \mathrm{~S}$ rRNA sequence obtained was compared with other Raffaelea spp. The $28 \mathrm{~S}$ rRNA sequences available in the GenBank for $R$. albimanens, $R$. ambrosiae, $R$. arxii, $R$. brunnea, $R$. canadensis, $R$. castellanii, $R$. ellipticospora, $R$. fusca, $R$. gnathotrichi, $R$. motetyi, $R$. quercivora, $R$. santoroi, $R$. subalba, $R$. subfusca, $R$. sulcati, $R$. sulphurea, $R$. tritirachium, and Raffaelea spp. were obtained and aligned with $R$. lauricola using CLUSTAL W to obtain 566 aligned characters (data not shown). Unique sequences specific to $R$. lauricola were detected and used to design two primers (LW28S-F1 and LW28SR1; Table 2) and a species-specific probe (LW28Sp; Fig. 4) to amplify a 84-bp segment. A BLAST search performed using this species-specific probe (LW28Sp) sequence (Table 2) has revealed a $100 \%$ match to only the $R$. lauricola 28 S sequence (EU17440) and not to any other fungal sequences represented in the GenBank, indicating that this sequence is unique and specific. Using this assay, a redbay $(\mathrm{Ct}$ value $=18.81$, specimen number 71975$)$, an avocado $(\mathrm{Ct}$ value $=17.81$, specimen number 71549) $($ Fig. 5), and a sassafras $(\mathrm{Ct}$ value $=22.15$, specimen number 62611) sample were screened and found to test positive for $R$. lauricola. Additional specimens were screened using this TaqMan assay. Redbay specimens $69678(\mathrm{Ct}$ value $=16.74), 72122(\mathrm{Ct}$ value $=22.26)$, and $72123(\mathrm{Ct}$ value $=31.87)$ and avocado specimens $66998(\mathrm{Ct}$ value $=16.64)$ and $72177(\mathrm{Ct}$ value $=27.26)$ were found to test positive for $R$. lauricola. One more avocado specimen (number 72178) displayed a high $\mathrm{Ct}$ value (37.79) but this could be due to low titer of fungal cells in the wood tissue. Fungal cultures were successfully generated from all these specimens (Table 1), and spore morphology was used to confirm their identity as $R$. lauricola. A control healthy, uninfected sample was included in all assays and they always produced a value similar to the no-DNA water control $(\mathrm{Ct}$ value $>39$ ). This tool is now routinely deployed to screen all suspected laurel wilt pathogen-affected tree samples received for testing. Over 250 samples have been screened successfully thus far using this TaqMan assay and their infection status determined as infected or healthy. All avocado specimens collected from commercial groves testing positive by molecular diagnosis were further confirmed by performing Koch's postulates by inoculating clean

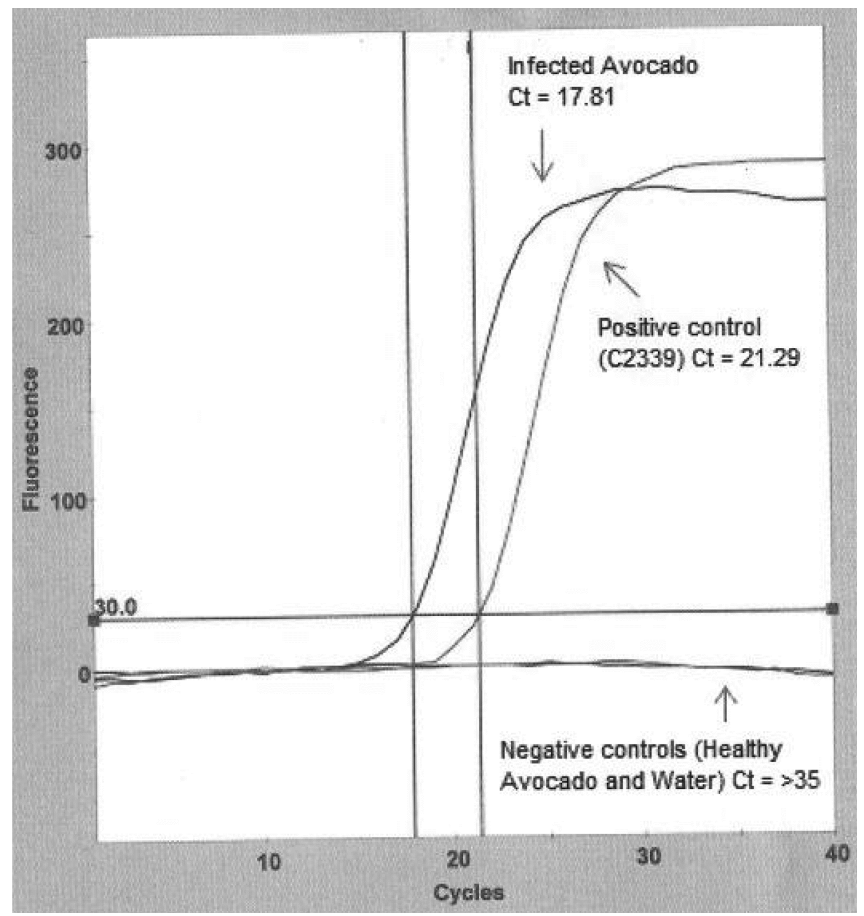

Fig. 5. TaqMan real-time polymerase chain reaction amplification identifies the presence of Raffaelea lauricola from a suspected avocado tree (specimen number 71549). Genomic DNA extracted from a healthy tree and this infected avocado tree tissues were amplified and compared with the $R$. lauricola type culture (C2339) grown on media (positive control) and a no-DNA water control (negative control). trees, observing their symptoms, successfully recovering the pathogen from inoculated plants, and performing morphological or molecular diagnosis.

\section{Discussion}

Amplification of rRNA markers (18S, ITS1-5.8S-ITS2, and 28S) has been routine and often deployed for fungal identification but amplification of $28 \mathrm{~S}$ and ITS sequences from $R$. lauricola turned out to be very difficult. This was attributed to premature enzyme stopping during the extension process, when Taq DNA polymerase encounters unusual sequences (GC- or AT-rich or tandem repeats) or a complex secondary structure (stem and loop and cruciform structures). A combination of Hf-PCR and dNTP mix containing 7deaza-dGTP has resolved this problem at both $28 \mathrm{~S}$ and ITS marker loci for $R$. lauricola, and successful amplifications were consistently achieved (Fig. 2). The 7-deaza-dGTP is an analogue that generates Hoogstein bond formation with $\mathrm{C}$ (two hydrogen bonds) instead of the usual Watson-Crick bond formation (three hydrogen bonds). This destabilizes the strong GC-rich stem and loop or cruciform structure and allows Taq to successfully complete the extension process (13). The partial $28 \mathrm{~S}$ sequences (545 bp) obtained earlier by Harrington et al. (9) seems to have succeeded in resolving two secondary structures (Fig. 3A and B) but the third structure (Fig. 3C) present close to the LR3 primer binding site has prevented the enzyme from completing the sequencing reaction.

Incorporation of 7-deaza-dGTP in the PCR products is also known to improve the downstream sequencing reaction (4). However, in the case of $R$. lauricola, sequencing of $28 \mathrm{~S}$ and ITS products containing 7-deaza-GTP was only partially successful and always failed near the LR3 primer binding site. This prompted a search for additional reagents to improve the sequencing reaction. Two additives, betaine and DMSO, are known to improve amplification through strong secondary structures $(4,11,13,20)$. These reagents facilitate strand separation of double-helix DNA and alter their annealing characteristics. Betaine or DMSO reduces annealing temperature, eliminates spurious GC-hydrogen bonding, and relaxes the secondary structure, resulting in more efficient and specific PCR product synthesis. A dGTP-BigDye Terminator v3.1 sequencing mix was recommended by the manufacturer (Life Technologies and Applied Biosystems) instead of the regular BigDye Terminator v3.0 sequencing mix for templates with strong secondary structures. Adding these three reagents into the sequencing reaction has allowed successful sequencing of the $28 \mathrm{~S}$ marker products from $R$. lauricola but the ITS marker products still contained a strong structure in the ITS1 spacer that could not be resolved.

The $28 \mathrm{~S}$ sequences obtained from $R$. lauricola have unique species-specific sequences (Fig. 4), and this allowed the design of a TaqMan real-time PCR probe for detecting laurel wilt from suspect trees. Real-time PCR has some advantages; it allows the screening of more samples and tends to be less labor intensive. Genomic DNA extracted from infected wood tissues could be readily amplified by a TaqMan real-time PCR assay (Fig. 5), eliminating the need to obtain a pure fungal culture for DNA extraction and amplification, and this has further reduced our molecular diagnosis turnaround time. This assay is now routinely deployed to detect and diagnose laurel wilt disease in Florida.

Avocado infection by $R$. lauricola was known (12) but this discovery is now further confirmed by molecular diagnosis and Koch's postulates. This is a cause for concern in Florida (5). Strategies to reduce the spread of this ambrosia beetle (X. glabratus) and the fungal pathogen ( $R$. lauricola) are urgently required to protect our avocado industry and forest ecosystem.

\section{Acknowledgments}

We thank D. Jones, Florida Department of Agriculture and Consumer Services, Division of Plant Industry, for technical assistance.

\section{Literature Cited}

1. Alamouti, S. M., Tsui, C. K. M., and Breuil, C. 2009. Multigene phylogeny of filamentous ambrosia fungi associated with ambrosia and bark beetles. 
Mycol. Res. 113:822-835.

2. Barnes, W. M. 1994. PCR amplification of up to 35-kb DNA with high fidelity and high yield from $\lambda$ bacteriophage templates. Proc. Natl. Acad. Sci. USA 91:2216-2220.

3. Cating, R. A., Hoy, M. A., and Palmateer, A. J. 2012. A comparison of standard and high-fidelity PCR: evaluating quantification and detection of pathogen DNA in the presence of orchid host tissue. Plant Dis. 96:480-485.

4. Dierick, H., Stul, M., Kelver, W. D., Marynen, P., and Cassiman, J-J. 1993. Incorporation of dITP or 7-deaza dGTP during PCR improves sequencing of the product. Nucleic Acids Res. 21:4427-4428.

5. Evans, E. A., Crane, J., Hodges, A., and Osborne, J. L. 2010. Potential economic impact of laurel wilt disease on the Florida avocado industry. HortTechnology 20:234-238.

6. Fraedrich, S. W., Harrington, T. C., Rabaglia, R. J., Ulyshen, M. D., Mayfield, A. E., III, Hanula, J. L., Eickwort, J. M., and Miller, D. R. 2008. A fungal symbiont of the redbay ambrosia beetle causes a lethal wilt in redbay and other Lauraceae in the southeastern United States. Plant Dis. 92:215-224.

7. Harrington, T. C., Aghayeva, D. N., and Fraedrich, S. W. 2010. New combinations in Raffaelea, Ambrosiella, and Hyalorhinocladiella, and four new species from the redbay ambrosia beetle, Xyleborus glabratus. Mycotaxon 111:337-361

8. Harrington, T. C., and Fraedrich, S. W. 2010. Quantification of propagules of the laurel wilt fungus and other mycangial fungi from the redbay ambrosia beetle, Xyleborus glabratus. Phytopathology 100:1118-1123.

9. Harrington, T. C., Fraedrich, S. W., and Aghayeva, D. N. 2008. Raffaelea lauricola, a new ambrosia beetle symbiont and pathogen on the Lauraceae. Mycotaxon 104:399-404.

10. Harrington, T. C., Yun, H. Y., Lu, S.-S., Goto, H., Aghayeva, D. N., and Fraedrich, S. W. 2011. Isolations from the redbay ambrosia beetle, Xyleborus glabratus, confirm that the laurel wilt pathogen, Raffaelea lauricola, originated in Asia. Mycologia 103:1028-1036.

11. Hengen, P. N. 1997. Optimizing multiplex and LA-PCR with betaine. Trends Biochem. Sci. 22:225-226.
12. Mayfield, A. E., III, Smith J. A., Hughes, M., and Dreaden, T. J. 2008. First report of laurel wilt disease caused by a Raffaelea sp. on avocado in Florida Plant Dis. 92:976.

13. McConlogue, L., Brow, M. A. D., and Innis, M. A. 1988. Structure-independent DNA amplification by PCR using 7-deaza-2'-deoxyguanosine. Nucleic Acids Res. 16:9869.

14. Rabaglia, R. J., Dole, S. A., and Cognato, A. I. 2006. Review of American Xyleborina (Coleoptera: Curculionidae: Scolytinae) occurring north of Mexico, with an illustrated key. Ann. Entomol. Soc. Am. 99:1034-1056.

15. Riggins, J. J., Hughes, M., Smith, J. A., Mayfield, A. E., III, Layton, B., Balbalian, C., and Campbell, R. 2010. First occurrence of laurel wilt disease caused by Raffaelea lauricola on redbay trees in Mississippi. Plant Dis. 94:634-635.

16. Saiki, R. K., Scharf, S., Faloona, F., Mullis, K. B., Horn, G. T., Erlich, H. A., and Arnheim, N. 1985. Enzymatic amplification of beta-globin genomic sequences and restriction site analysis for diagnosis of sickle cell anemia. Science 230:1350-1354.

17. Smith, J. A., Dreaden, T. J., Mayfield, A. E., III, Boone, A., Fraedrich, S W., and Bates, C. 2009. First report of laurel wilt disease caused by Raffaelea lauricola on sassafras in Florida and South Carolina. Plant Dis. 93:1079.

18. Smith, J. A., Mount, L., Mayfield, A. E., III, Bates, C. A., Lamborn, W. A., and Fraedrich, S. W. 2009. First report of laurel wilt disease caused by Raffaelea lauricola on camphor in Florida and Georgia. Plant Dis. 93:198.

19. White, T. J., Bruns, T., Lee, S., and Taylor, J. W. 1990. Amplification and direct sequencing of fungal ribosomal RNA genes for phylogenetics. Pages 315-322 in: PCR Protocols: A Guide to Methods and Applications. M. A. Innis, D. H. Gelfand, J. J. Sninsky, and J. White, eds. Academic Press, New York.

20. Winship, P. R. 1989. An improved method for directly sequencing PCR amplified material using dimethyl sulphoxide. Nucleic Acids Res. 17:1266.

21. Zuker, M. 2003. Mfold web server for nucleic acid folding and hybridization prediction. Nucleic Acids Res. 31:3406-3415. 